\title{
Liquid baits control Argentine ants sustainably in coastal vineyards
}

\author{
by Monica L. Cooper, Kent M. Daane, \\ Erik H. Nelson, Lucia G. Varela, Mark C. Battany, \\ Neil D. Tsutsui and Michael K. Rust
}

\section{Liquid ant baits are an alterna-} tive to broad-spectrum insecticide sprays conventionally used to control Argentine ants. We review the development of liquid ant baits, which capitalize on the ants' sugarfeeding requirements and social structure to deliver small doses of toxicant throughout the colony. The ant bait program described here, developed for commercial vineyards, also has the potential to facilitate the use of biological controls for mealybug and scale pests. The implementation of an Argentine ant bait program will enable grape growers to target other pests more selectively with insecticides, further contributing to their sustainable viticulture practices.

7 he Argentine ant is an invasive pest I that has spread throughout California since it was first reported from Ontario, Calif., in 1905. Though popularly recognized as a household pest (Vega and Rust 2001), the Argentine ant (Linepithema humile [Mayr]) also causes severe problems in natural systems by displacing native ants and other insect species, and even some vertebrate and plant populations (Holway et al. 2002). In addition, in agricultural systems the Argentine ant is associated with outbreaks of phloem-feeding insects such as mealybugs, scale and aphids, which the ants protect from natural enemies; in exchange, the ants collect the sugarrich food source (honeydew) excreted by the phloem-feeders (Buckley and Gullan 1991).

In California vineyards, the Argentine ant has been implicated in outbreaks of three mealybugs species:

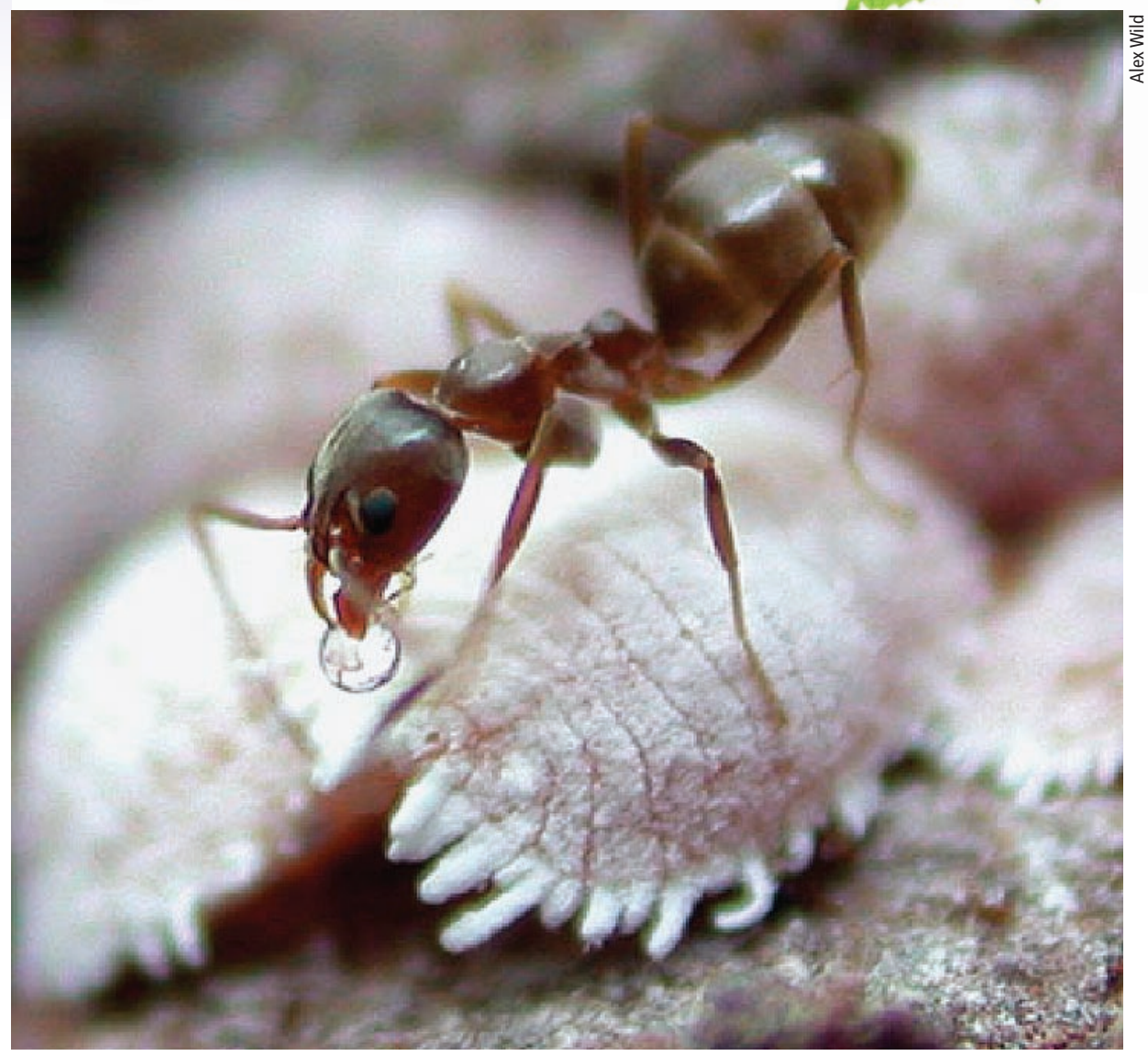

An Argentine ant tends an adult mealybug. A drop of honeydew, the sugar-rich mealybug excretion, can be seen in the ant's mouthparts.

grape mealybug (Pseudococcus maritimus [Ehrhorn]), obscure mealybug (P. viburni [Signoret]) (Daane et al. 2007; Phillips and Sherk 1991) and vine mealybug (Planococcus ficus [Signoret]), a particularly severe pest that recently invaded California (Daane, Bentley, et al. 2006). Mealybug feeding may partially defoliate vines, and crop damage results when mealybugs infest bunches and excrete honeydew, which promotes the growth of sooty molds and bunch rots (Godfrey et al. 2002). Mealybugs also indirectly damage vines by vectoring leafroll viruses (Golino et al. 1999) (see page 156).

To reduce vineyard damage from mealybugs and promote their biological control (see page 167), the Argentine ant must be suppressed. We review the development of liquid ant baits, which capitalize on the ants' sugar-feeding requirements and social structure to deliver small doses of toxicant through- out the colony. We also discuss future avenues of study to further control Argentine ant populations.

\section{Argentine ant biology}

In agricultural systems, Argentine ants are most commonly found in areas with disturbed habitats and some soil moisture. Their nests are composed of reproductive females (queens), sterile females (workers), winged reproductive males and immature ants (eggs, larvae and pupae). Outside the species' native range, the social structure and biology of the Argentine ant have increased its pest status. In its introduced range, Argentine ant nests are unicolonial, forming massive "supercolonies" characterized by the absence of aggression among workers across large geographic areas (Tsutsui et al. 2000). The main European supercolony has been reported to extend up to 3,700 miles (6,000 kilometers), en- 


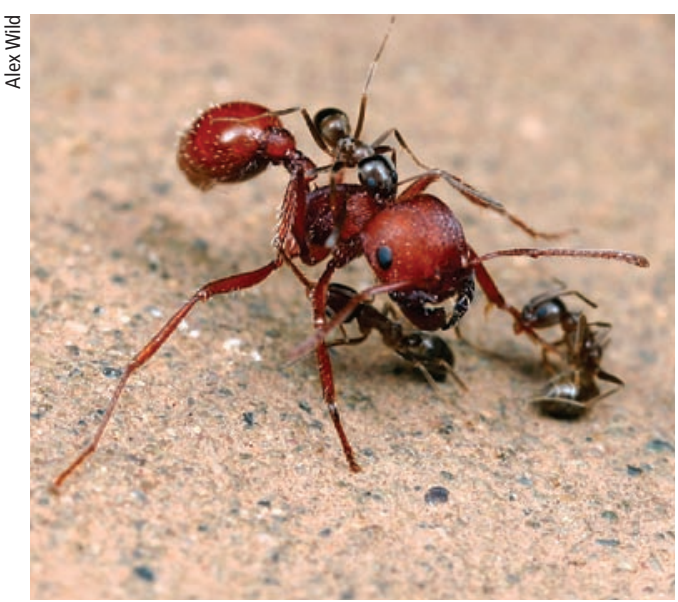

Argentine ants are aggressive and social. Above, three Argentine ants attack the native harvester ant (Pogonomyrmex subdentatus) en masse.

compassing millions of nests and comprising billions of workers (Giraud et al. 2002). In the absence of aggression and territoriality, more resources can be directed to colony growth, the domination of food and nesting resources, and the displacement of native ants in direct, aggressive encounters (Holway et al. 1998).

However, the ants' biology can also be used against them. The Argentine ant diet is composed mainly of carbohydrates (sugars) in a liquid form, such as honeydew (Rust et al. 2000). Therefore, while granular protein baits are not heavily foraged by Argentine ant workers, sugar water laced with insecticide is an excellent method for delivering small but lethal amounts of toxicant to the colony (Silverman and Roulston 2001). Liquid baits exploit the social behavior of ants to distribute toxicant to colony members, including larvae and queens (Silverman and Roulston 2003). Argentine ants also use persistent trail pheromones to recruit colony members to food resources, resulting in fidelity to bait-station locations

(Aron et al. 1989; Vega and Rust 2001). Because bait is exchanged among colony members via trophallaxis (i.e., ants feeding other ants), baits have the potential to affect the nest population and provide season-long control (Forschler and Evans 1994; Klotz et al. 2006).

Liquid baits reduce undesirable environmental impacts because they require a relatively small amount of insecticide, and the dispenser design can minimize insecticide delivery to nontarget insects including predators and pollinators (Taniguchi et al. 2005). In contrast, broad-spectrum insecticide sprays targeted at ants may disrupt integrated pest management (IPM) programs by suppressing populations of beneficial insects. While these sprays may also kill foraging ants, unlike baits they have little effect on ants in nests and so allow for an eventual resurgence of the population (Klotz et al. 2002; Rust et al. 1996).

\section{Developing liquid baits}

Ant control in vineyards has been investigated using granular protein baits for Formica species (Klotz et al. 2003; Tollerup et al. 2004) and liquid sugar baits for Argentine ants (Daane, Sime, et al. 2006; Daane et al. 2008; Nelson and Daane 2007). The liquid bait trials discussed here were conducted either in Central Coast vineyards (San Luis Obispo, Santa Barbara and Monterey counties) populated with obscure mealybug, or in North Coast vineyards (Napa and Sonoma counties) populated with grape mealybug. The initial liquid bait trials were conducted from 2000 to 2002, based on methodologies developed for urban systems by Klotz et al. (2002) and described in detail by Daane, Sime, et al. (2006).

In brief, the liquid baits were composed of 25\% sugar water laced with a small dose of one of four different toxicants, and were deployed in approximately 250 - to 500-milliliter containers placed on the ground or attached to the vine trunk. Treatments were replicated four to six times in large experimental plots ranging from 0.25 to 0.5 acre ( 0.1 to 0.2 hectare) to account for the movement of Argentine ants, which forage up to 150 feet from their nests (Ripa et al. 1999).

Ant feeding activity was used to quantify ant densities and was based on the amount of nontoxic sugar water ants removed from 50-milliliter plastic tubes (monitoring tubes). Sugar-water removal rates are related to ant density because each milliliter removed represents approximately 3,300 ant visits to the monitoring tube (Greenberg et al. 2006).

Mealybug densities were assessed using 2.5-to-3-minute visual searches of randomly selected vines (timed counts), based on methodologies developed by Geiger and Daane (2001). Near harvest, crop damage was measured by rating fruit clusters on a scale from 0 to 3 : “ 0 " represents no mealybugs; " 1 " represents 1 to 10 mealybugs and/or honeydew;

"2" represents more than 10 mealybugs, sooty mold and/or honeydew; and "3" represents heavily infested, unmarketable clusters.

Because most insecticides are not highly soluble in water, one of the major challenges facing the study group was to find suitable toxicants that can be formulated into sugar water solutions. The first vineyard trials were in 2000 and 2001, and compared a no-bait control to four liquid bait treatments: boric acid $(0.5 \%)$, imidacloprid $(0.0001 \%)$, fipronil $(0.0001 \%)$ and thiamethoxam $(0.0001 \%)$. These initial trials showed little difference between the no-bait control and the liquid bait treatments.

However, valuable lessons were learned and applied to subsequent trials, in which measurable differences were recorded among treatments (Daane, Sime, et al. 2006). First, bait stations left in the field for longer than 3 weeks, without the addition of preservative, fouled as the sugar fermented. Second, unlike the urban systems tested, the vineyards had incredibly large Argentine ant populations: up to 1.2 ounces ( 35 grams) of sugar water per day were removed from monitoring tubes, the equivalent of more than 100,000 ant visits!

In a later trial in 2002, researchers refilled and cleaned the bait stations every 2 weeks to reduce bait fermentation, increased the distance between

\section{The ants" biology can be used against them.}

plots to keep the large ant population from spilling over between treatment plots, and increased the number of bait stations deployed from 35 per acre $(85$ per hectare) to 65 to 250 per acre (160 to 620 per hectare). The researchers also used only one bait formulation (0.0001\% thiamethoxam) and deployed bait stations earlier in the season to take advantage of spring foraging activity. With these changes, researchers recorded significant differences in Argentine ant feeding activity and mealybug crop damage between the bait and no-bait treatments with the liquid bait treatment (fig. 1). 

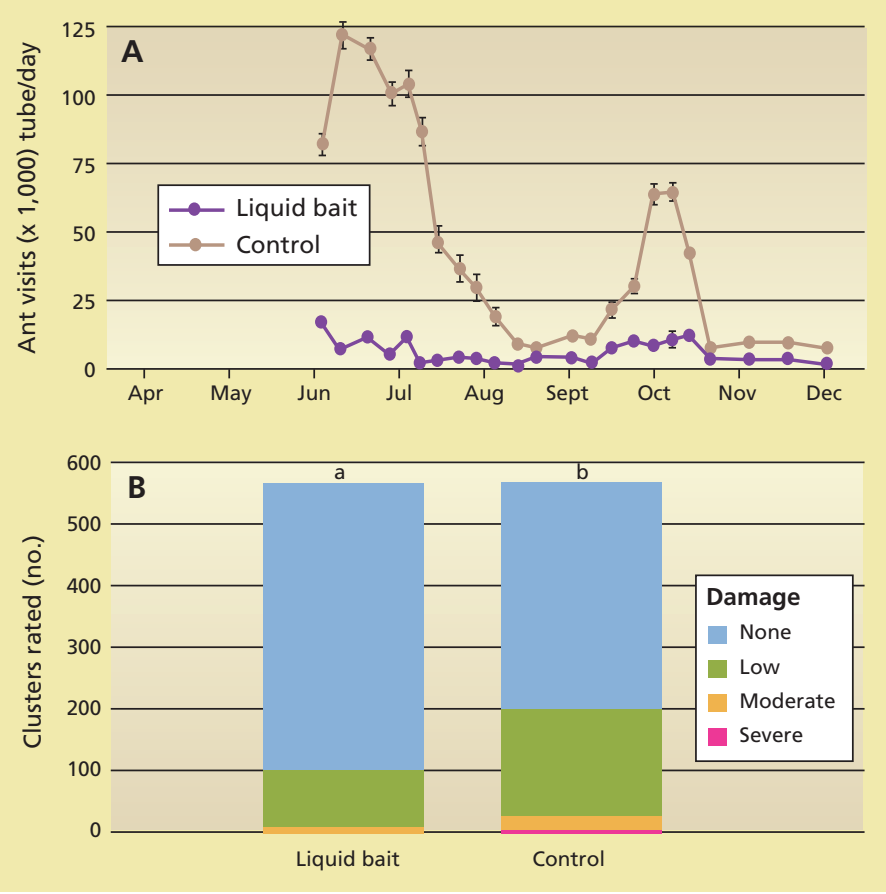

Fig. 1. Comparison of liquid ant bait $(0.0001 \%$ thiamethoxam in $25 \%$ sugar water) and no-bait control in a North Coast vineyard for $(A)$ ant visits to monitoring tubes $(F=28.981, d f=1,6, P=$ 0.002 ) and (B) crop damage as rated Sept. 17-19, 2002 (Pearson's $\left.\chi^{2}=44.72, \mathrm{df}=3, P<0.001\right)$. Source: Daane, Sime, et al. 2006.
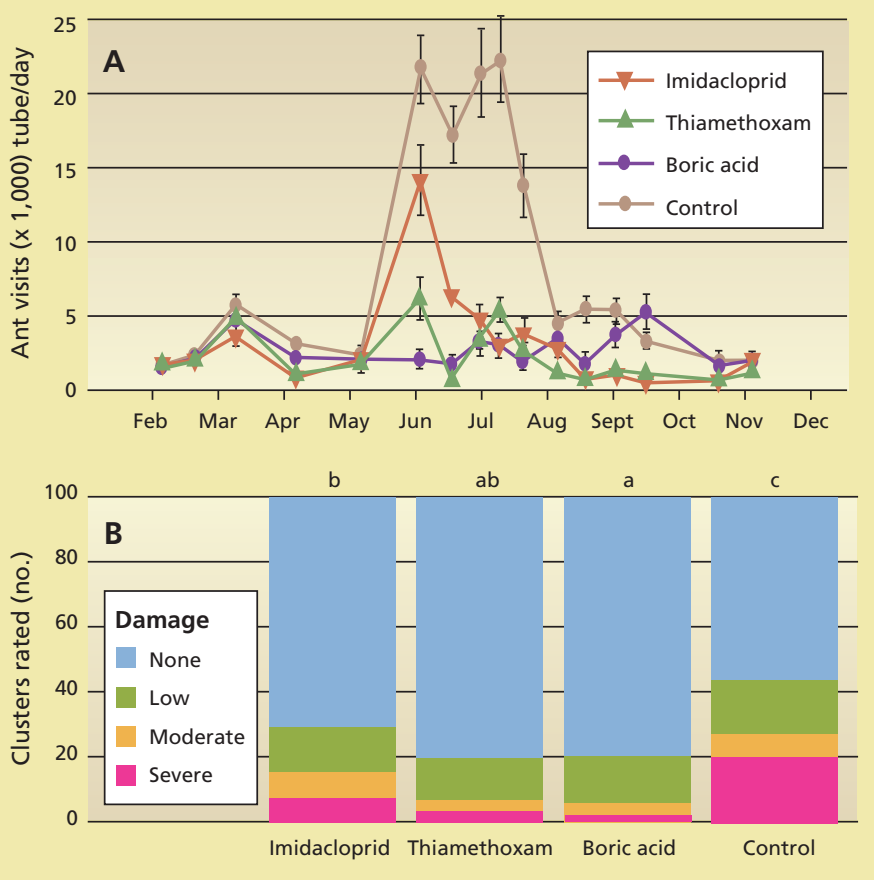

Fig. 2. Comparison of liquid ant baits with different toxicants and a nobait control in a Central Coast vineyard for (A) ant visits to monitoring tubes and (B) crop damage as rated on Oct. 14, 2003 (letters above each treatment bar indicate a significant difference using pairwise comparisons for Pearson's chi-square test). Source: Daane et al. 2008, where complete statistical description is provided.

\section{Evaluating toxicants}

Results from the 2002 trial showed that liquid baits could, in principle, be used to lower Argentine ant densities (Daane, Sime, et al. 2006). However, in practice grower adoption would require answers to the following critical questions: What toxicant would be used, and would it be available as a commercial formulation? What bait station could be used? How many bait stations are needed per acre? At what time of year should baiting begin, and should bait be deployed continuously or seasonally?

Using the improved bait-station deployment methods, researchers reevaluated different toxicants by testing the impact of liquid baits containing either boric acid $(0.5 \%)$, imidacloprid $(0.0001 \%)$ or thiamethoxam $(0.0001 \%)$ against a no-bait control (Daane et al. 2008). As before, large plots were located in commercial vineyards, and liquid baits were delivered in plastic containers deployed at about 50 per acre (160 per hectare).

Results showed that the thiamethoxam and boric acid treatments consistently and significantly reduced ant feeding activity measured by monitoring tubes, mealybug density measured by timed counts and fruit damage ratings (fig. 2).
The poor results with imidacloprid were attributed to rapid photodegradation of this toxicant and to the low concentration of active ingredient. Because the imidacloprid concentration in the bait $(0.0001 \%)$ was below the reported, delayed toxicity range $(0.00071 \%$ to $0.0092 \%$ ) (Rust et al. 2004), it may have killed some foraging ants, but did not have the desired colonywide impact.

The formulation of liquid baits can be tricky: the concentration of active ingredient must be great enough to cause ant mortality yet low enough to be slow-acting (killing ants in 1 to 4 days), allowing ample time for bait to spread throughout the colony and remain attractive to foraging ants (Rust et al. 2004). The range of suitable concentrations for a variety of toxicants has been delineated in laboratory trials, and baits with toxicant levels within these ranges are referred to as having delayed toxicity (Hooper-Bui and Rust 2000; Klotz et al. 2000; Rust et al. 2004).

\section{Commercial bait products}

The next phase of the bait program was to test commercially formulated bait products, including a liquid bait containing imidacloprid $(0.005 \%)$, a granular protein bait containing spinosad $(0.015 \%)$ and a liquid bait containing spinosad (0.015\%) (Daane et al. 2008). Researchers used methodologies similar to those described previously, except that the bait stations were shielded from light with Styrofoam containers to protect against degradation of the toxicants. Results again demonstrated the suppressive impact that liquid baits have on Argentine ant and mealybug populations (fig. 3). Granular spinosad bait had no impact on ant populations, while both the spinosad and imidacloprid liquid baits significantly lowered ant densities. This result reaffirmed the need for a liquid sugary bait to target the Argentine ant rather than a granular protein bait (Aron et al. 2001; Rust et al. 2000).

As a result of this research, several liquid ant-bait products are now available for use in agricultural systems, and others may become available in the future. The registered products include Vitis (imidacloprid, Bayer CropScience), Gourmet Liquid Ant Bait (borate, Innovative Pest Control Products) and Tango (methoprene, Wellmark International). During the 2007 season growers began using these products in commercial vineyards and 
orchards in five California counties, independent of research activities. Ongoing efficacy trials will determine the long-term impacts of these baits on Argentine ant populations (Cooper and Daane, unpublished data).

\section{Bait-station design}

A commercially acceptable bait station for vineyards should protect the bait from degradation, be easily moved but sturdy, be relatively inexpensive or long-lasting, and hold enough bait so that it must be filled only once per season, provided the bait is formulated with preservative to prevent spoilage. The KM AntPro dispenser consists of a central reservoir that slowly releases bait in response to ant feeding. It has been used successfully in Argentine ant trials in citrus orchards (Greenberg et al. 2006). A bait station developed by UC researchers, which consists of an outer

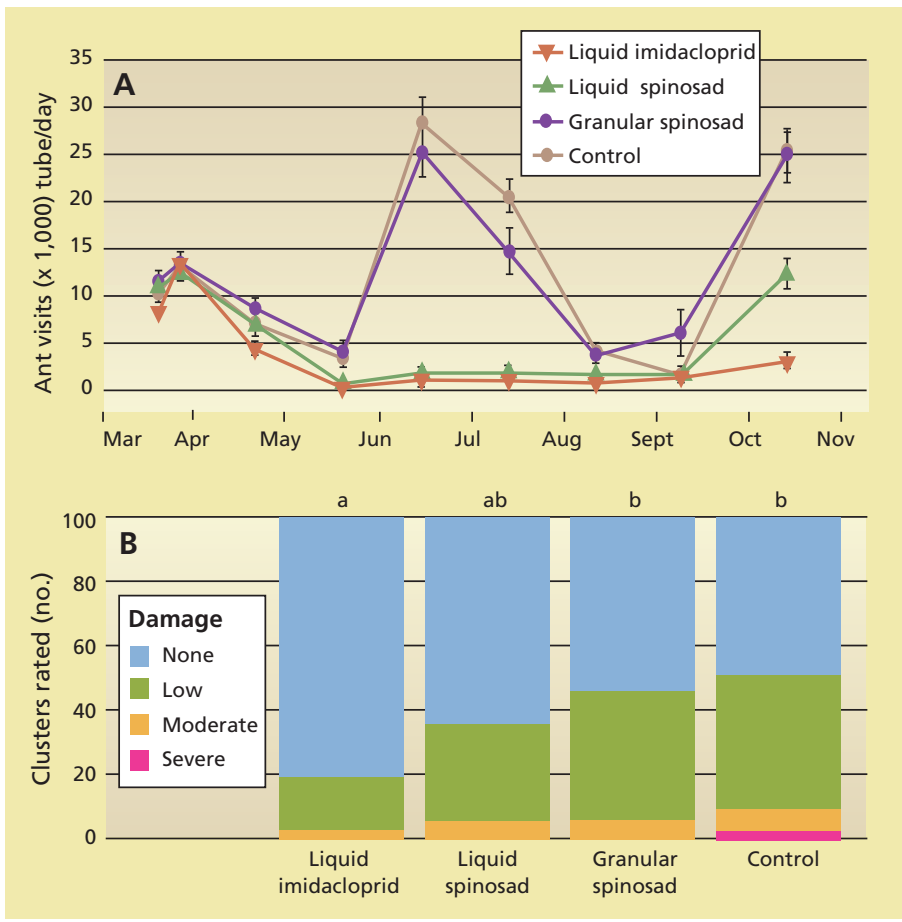

Fig. 3. Comparison of ant baits with different commercial baits and a no-bait control in a North Coast vineyard for (A) ant visits to monitoring tubes and (B) crop damage as rated on Aug. 16, 2004 (letters above each treatment bar indicate a significant difference using pairwise comparisons for Pearson's chi-square test). Source: Daane et al. 2008, where complete statistical description is provided.
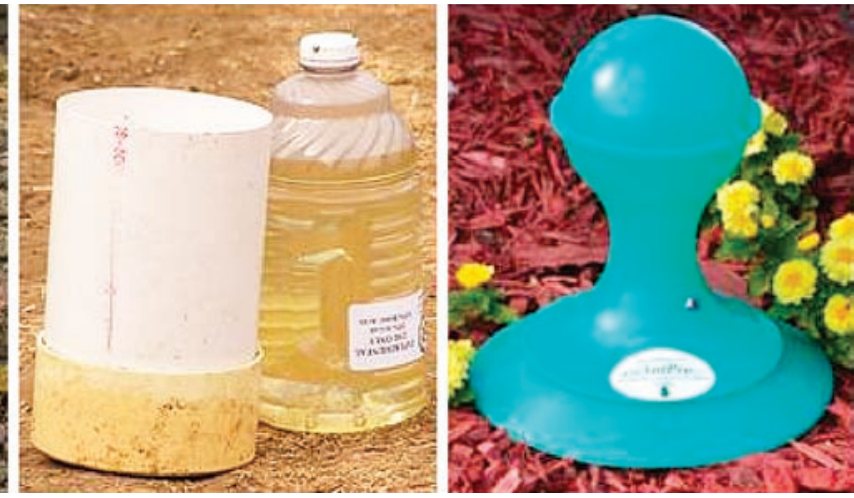

Liquid ant-bait stations registered for use in vineyards and orchards by the ChemSAC arm of the U.S. EPA (fall 2005) include the UC-designed PVC station, left and center, with bait reservoir, and, right, the KM AntPro station (www.kmantpro.com).

protective PVC housing and an inner disposable bait bottle, has been used in large-scale commercial vineyard trials since 2004. Both bait stations were approved in 2005 for use in vineyards and orchards by the ChemSAC arm of the U.S. Environmental Protection Agency.

\section{Densities for effective control}

In urban systems, researchers were able to affect the relatively small Argentine ant populations by placing stations at very low densities (Klotz et al. 2006). In vineyards, however, bait stations were deployed at much higher densities to produce measurable effects on ant populations (Daane, Sime, et al. 2006). To determine how many bait stations are needed, Nelson and Daane (2007) compared a range of densities (0 to 91 per acre, or up to 225 per hectare) in commercial vineyards, and measured the impact on ant density and mealybug fruit-infestation levels.

The results showed that incremental increases in bait-station density had an increasingly suppressive effect on both ant activity and mealybug abundance in fruit clusters (fig. 4). However, the data did not indicate a particular bait density that maximized ant or mealybug suppression. Rather, the results suggest that all investigated bait densities will provide some reduction in ant activity and mealybug damage. This work implies that the optimal bait-station density may depend on the size of the local Argentine ant population. Higher densities may be required to achieve measurable ant control within one or two seasons, particularly in vineyards with higher ant densities. In subsequent seasons, as the ant population declines, continued suppression may be achieved with fewer bait stations per acre.

The optimal bait-station density is determined in part by the distance that ants travel from the nest to locate food. Foraging distance has been investigated for Argentine ants in urban environments (Vega and Rust 2003) and citrus groves (Ripa et al. 1999). Sugar water labeled with rabbit immunoglobin $G$ protein was used to study ant movement in vineyards (Daane, Cooper, et al. 2006). The percentage of ants carrying protein-labeled sugar water, as determined by a sandwich enzyme-linked immunosorbent assay (ELISA), declined sharply as distance from the bait station increased (fig. 5). In the 6 days following the placement of sugar water in the field, most bait movement was limited to within 66 feet (20 meters) of the stations; beyond 66 feet, fewer than $10 \%$ of the ants were carrying the bait. However, a few ants at the most distant sample points did test positive, showing that ants occasionally carried the sugar water more than 236 feet (72 meters). Bait movement appears to be highly localized in the first 6 days after a bait station is placed.

We expected trellising along rows to facilitate bait movement, and row middles to impede bait movement. But surprisingly, the movement of bait 


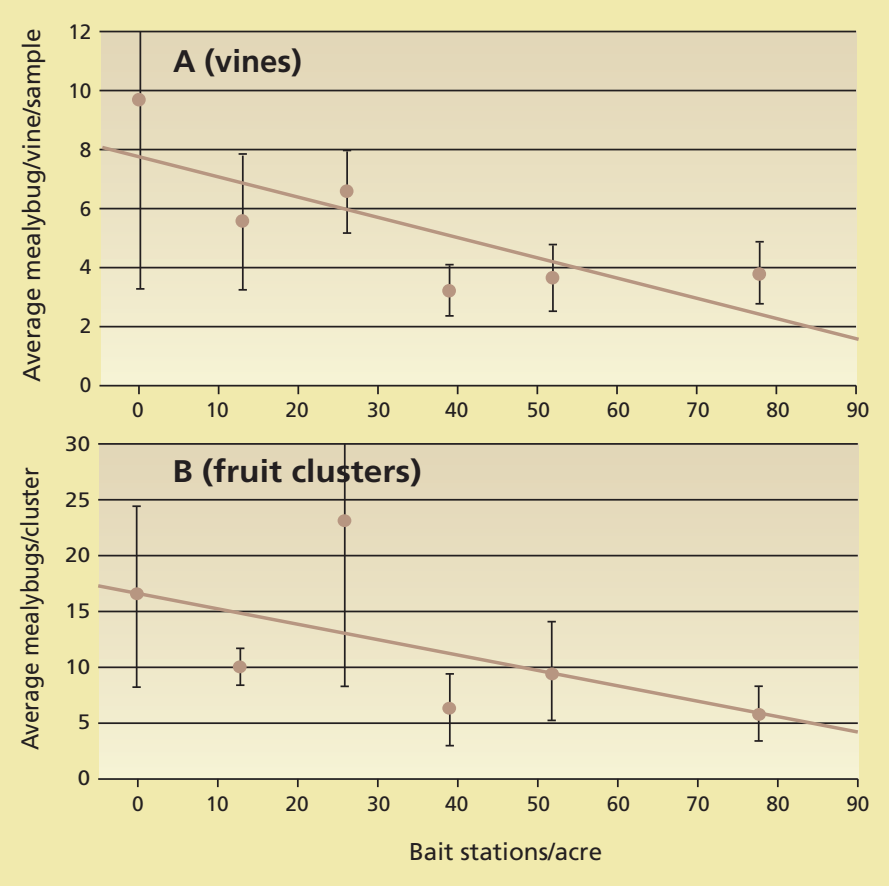

Fig. 4. Bait-station density and grape mealybug abundance $(A)$ on vines during the growing season and (B) in fruit clusters at harvest, showing a significant negative relationship. Bait stations were deployed at 0 to 78 stations per acre. Source: Nelson and Daane 2007.

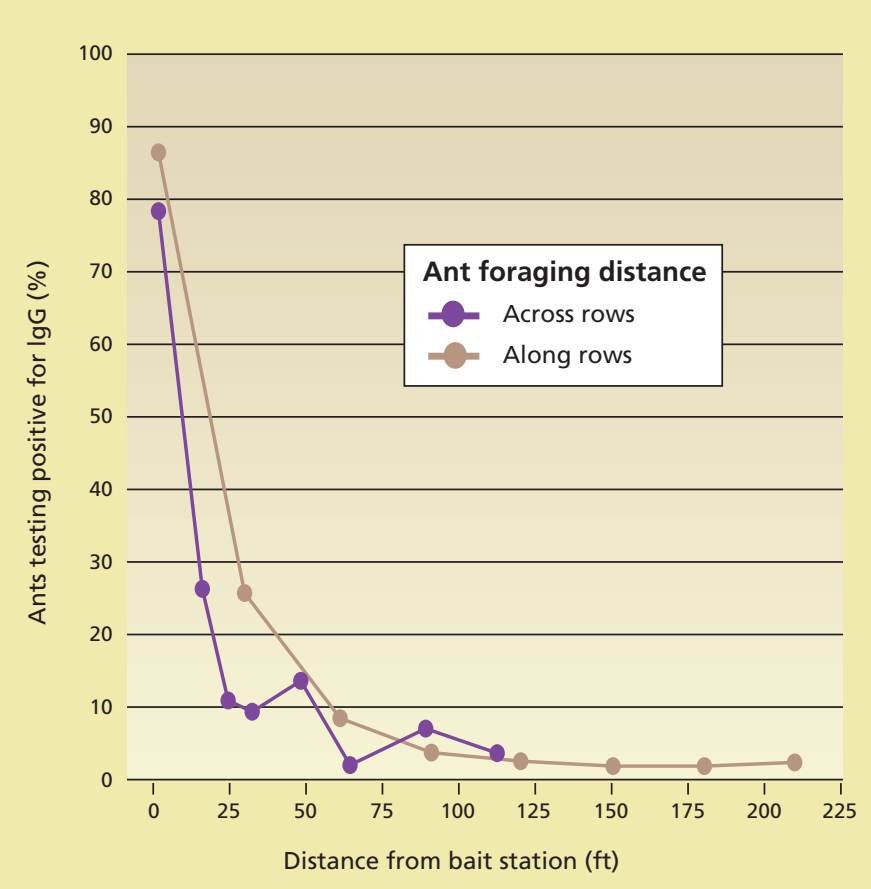

Fig. 5. Movement by Argentine ant of sugar water labeled with rabbit protein (IgG) collected 6 days following initiation of treatment; $y$-axis shows proportion of ants that tested positive for the rabbit protein. Data are averages of four plots in a Sonoma County vineyard. Movement across and along rows was not significantly different. across vineyard rows was similar to movement along rows. This result suggests that bait stations do not need to be placed in every row, but may be placed in every second or third row.

\section{Timing and duration}

Liquid baits target Argentine ant larvae and therefore, should be deployed during periods of peak larval development and active nest expansion. To delineate these periods, Argentine ant nests were collected monthly from April 2004 to May 2006 at a vineyard in San Luis Obispo County. Using a flotation method, dead ants were separated from small batches of nest soil (1.8 to 3.5 ounces, or 50 to 100 grams) and then categorized into eight recognized life stages: egg, worker larva, worker pupa and sterile adult worker; and reproductive larva, reproductive pupa, male and queen.

This study found that Argentine ant reproductive larvae are most numerous in April, and that worker larvae are present virtually yearround (fig. 6). Therefore, bait deployed during April and May has the greatest potential to affect colony development and expansion by targeting the reproductive lar- vae. This period is considered essential to decreasing the effective mating population. Although worker larvae continue to populate the nest from July to September, ant foraging activity at bait stations and monitoring tubes declines during this time (figs. 1, 3), due in part to the prevalence of alternative food

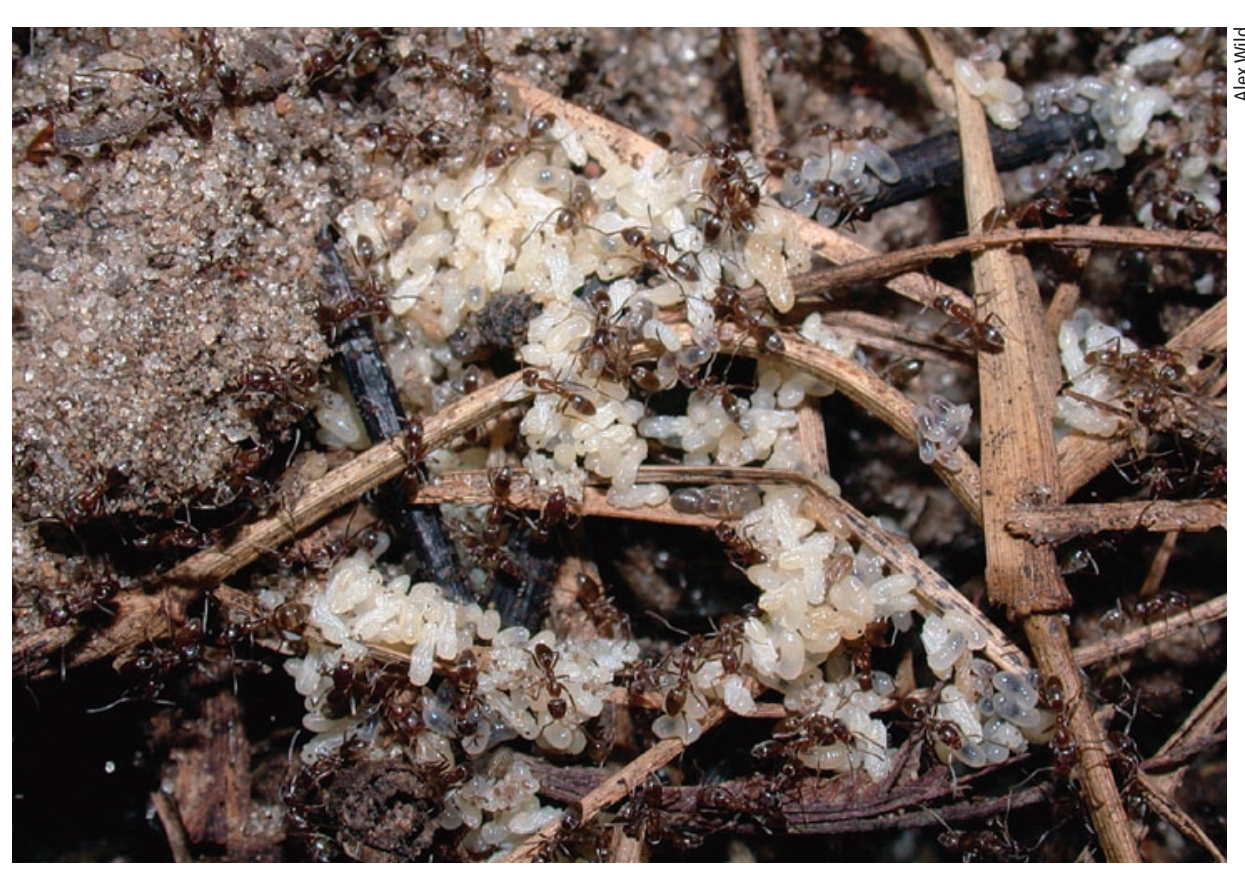

An Argentine ant nest in northern Argentina shows various life stages: egg, larva, pupa and adult. resources such as mealybug honeydew and ripening grapes in the vineyard.

This foraging shift toward alternative food resources reflects typical Argentine ant behavior in agricultural settings and has been well documented in citrus groves, where the number of aphids and scale insects tended by 


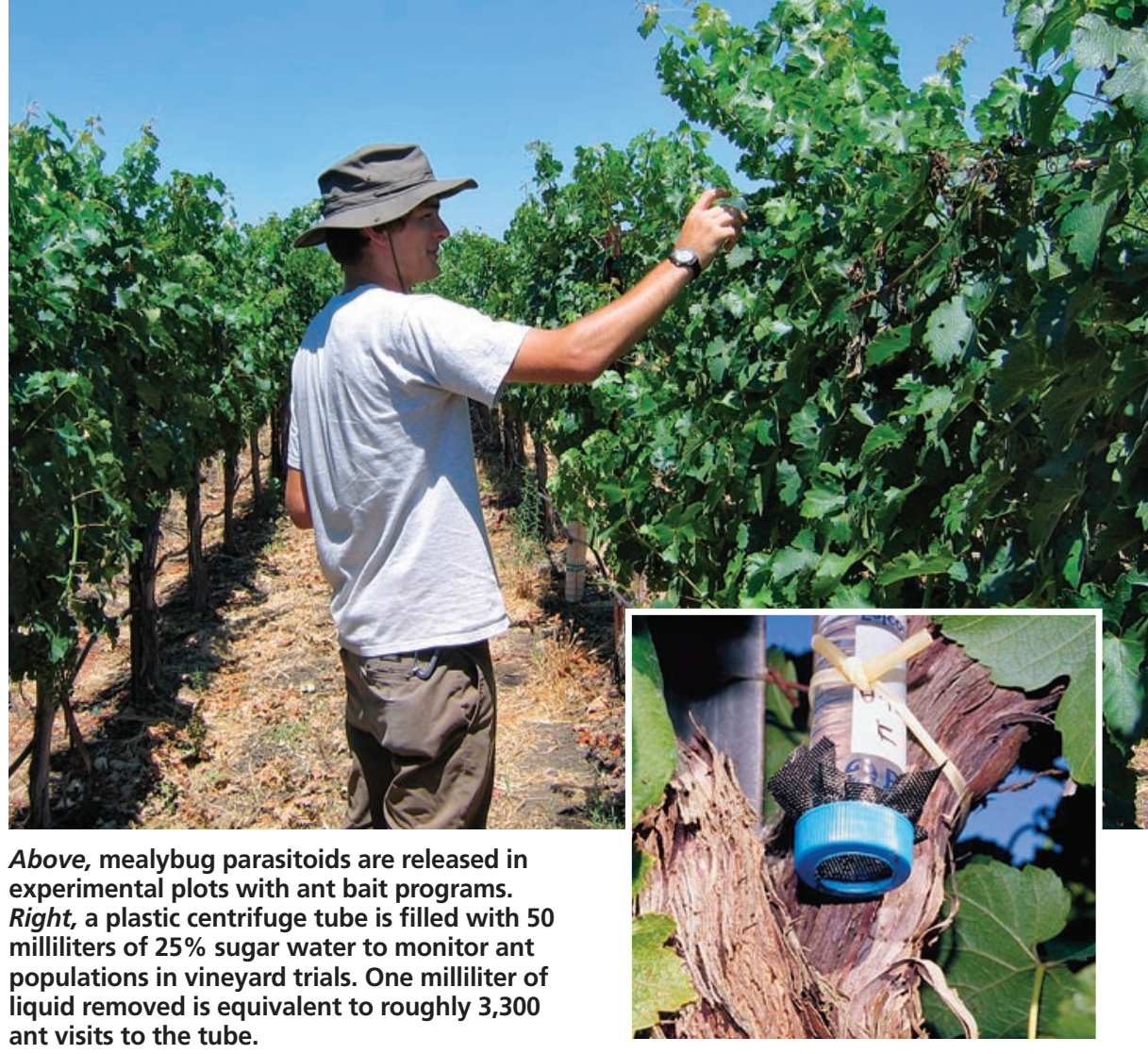

Argentine ants increases dramatically from June to October (Horton 1918; Newell and Barber 1913). Warm weather and favorable foraging conditions after harvest result in a second, shorter, intensive foraging period (figs. 1, 3) in October, which may also be exploited, with toxic bait affecting the remaining larvae and the overwintering adult population. Argentine ants typically constrict their range in the winter months (Markin et al. 1970) in response to cool, wet weather. Therefore, foraging from November to March is extremely light due to these climatic factors and because there are fewer larvae in the nest during this time.

These results suggest that to have the maximum impact on ant populations, baits should be deployed in early

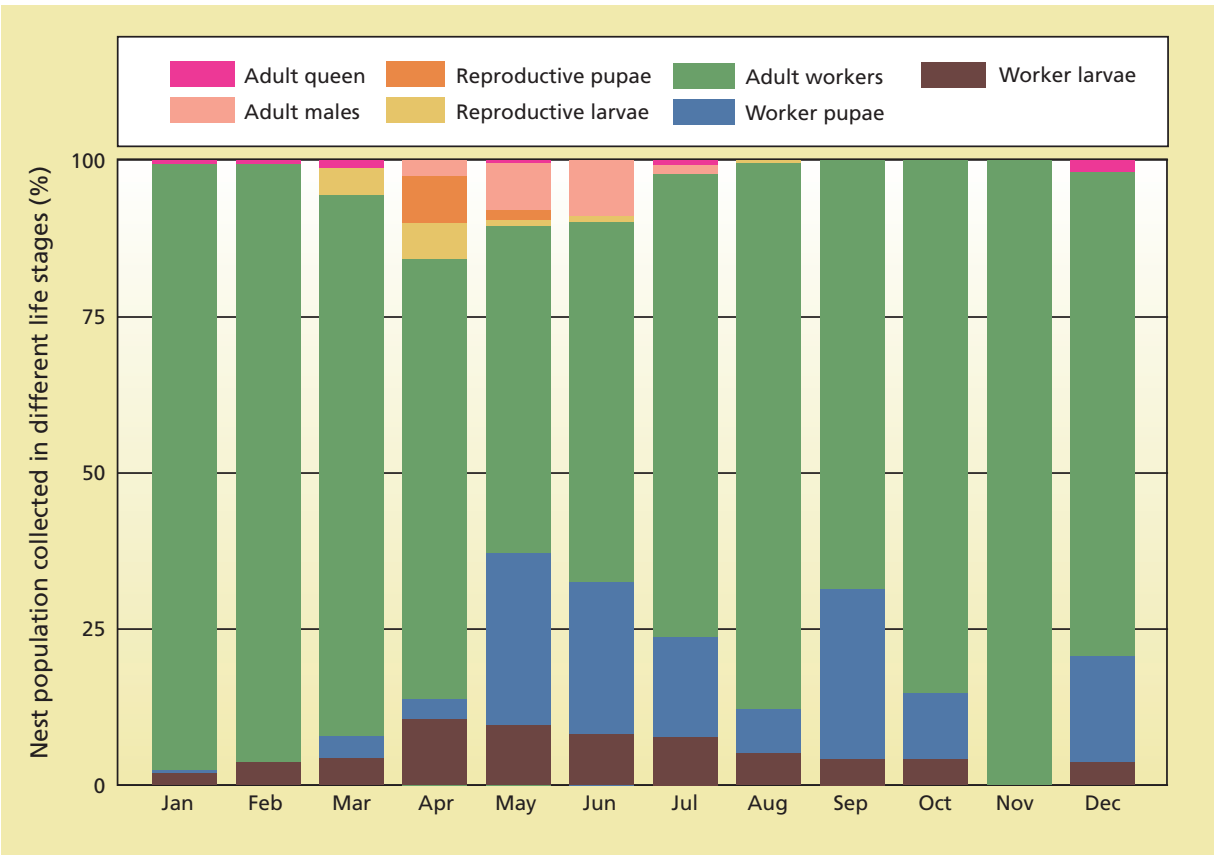

Fig. 6. Argentine ant life cycle in coastal California vineyards, based on averaged data from nest collections in a San Luis Obispo County vineyard, 2004-2006. Data presented as percentage of nest population in recognized life stages.

spring to target developing larvae especially those that will become new queens and males - and to coincide with a period of active foraging by ant workers. Ongoing trials investigating the impact of various bait-deployment periods will further elucidate the links between timing and duration of bait deployment as it affects Argentine ant and mealybug populations.

\section{Future directions}

Grape growers now have at their disposal a sustainable Argentine ant management tool that is an alternative or companion to broad-spectrum insecticides. The registered bait products and stations that arose from this work allowed growers to begin implementing this program on a commercial scale in 2007. Continuing research on the density and timing of bait-station deployment has the potential to improve the program's effectiveness and lower costs, thereby facilitating broader implementation.

Concurrently, the expanded production and release of natural enemies will provide better biological control of vineyard mealybugs. Ongoing studies are evaluating the impact of the Argentine ant on developing parasitoids, as well as delineating the mealybug's production cycles of honeydew and attractiveness to tending ants. Future studies in vineyard landscapes where Argentine ant populations are declining in response to bait treatments will examine impacts on the distribution patterns of nontarget ants. Also, data reported here was collected in fields populated with either grape or obscure mealybug; the program has since been expanded to include work in fields populated with the invasive vine mealybug and European fruit lecanium scale, Parthenolecanium corni (Bouché).

In the future, the methods described here may be supplemented by the use of semiochemicals, including pheromones, allomones, kairomones, attractants and repellents that modify ant behavior. For example, trail pheromones or other chemical attractants could be used to enhance recruitment to bait (Greenberg and Klotz 2000) or to permit the use of fewer bait stations in a given area. 
Alternatively, studies focusing on the chemical ecology of the Argentine ant may reveal methods for disrupting their foraging or inducing aggression among nest mates. These newly explored control methods, combined with the liquid baits described here, hold promise for advancing IPM strategies for the Argentine ant in managed ecosystems. In a broader sense, the ant management system developed and tested in vineyards can be applied to other managed and natural ecosystems that have been disrupted by the presence of Argentine ants. Ultimately, this program has the potential to minimize the use of broadspectrum chemicals and facilitate the use of sustainable and IPM practices.

M.L. Cooper is Staff Research Associate,

K.M. Daane is Cooperative Extension Specialist, and E.H. Nelson is Postdoctoral Researcher, Department of Environmental Science, Policy and Management, UC Berkeley; L.G. Varela is Integrated Pest Management (IPM) Advisor, UC Statewide IPM
Program and UC Cooperative Extension (UCCE) Sonoma County; M.C. Battany is Farm Advisor, UCCE San Luis Obispo County; N.D. Tsutsui is Assistant Professor, Department of Environmental Science, Policy and Management, UC Berkeley; and M.K. Rust is Professor, Department of Entomology, UC Riverside. We thank California Department of Food and Agriculture for funding this review; and the America Vineyard Foundation, California Table Grape Commission, California Raisin Marketing Board, Viticulture Consortium and Central Coast Vineyard Team for funding this research. We gratefully acknowledge the cooperation of growers in Monterey, Napa, San Luis Obispo, Santa Barbara and Sonoma counties.

\section{References}

Aron S, Keller L, Passera L. 2001. Role of resource availability on sex, caste, reproductive allocation ratios in the Argentine ant Linepithema humile. J Anim Ecol 70:831-9.

Aron S, Pasteels JM, Deneubourg JL. 1989. Traillaying behavior during exploratory recruitment in the Argentine ant, Iridomyrmex humilis Mayr. Biol Behav 14:207-17.

Buckley R, Gullan P. 1991. More aggressive ant species (Hymenoptera: Formicidae) provide better protection for soft scales and mealybugs (Homoptera: Coccidae, Pseudococcidae). Biotropica 23:282-6.

Daane KM, Bentley WJ, Walton VM, et al. 2006 New controls investigated for the vine mealybug. Cal Ag 60:31-8.

Daane KM, Cooper ML, Nelson EH, et al. 2006. Investigation of Argentine ant biology and control methods in California vineyards. In: American Vineyard Foundation Annual Reports, Crop Year 2005.

Daane KM, Cooper ML, Sime KR, et al. 2008. Testing baits to control Argentine ants (Hymenoptera: Formicidae) in vineyards. J Econ Entomol 101:699-709.

Daane KM, Sime KR, Fallon J, Cooper ML. 2007. Impacts of Argentine ants on mealybugs and their natural enemies in California's coastal vineyards. Ecol Entomol 32:583-96.

Daane KM, Sime KR, Hogg BN, et al. 2006. Effects of liquid insecticide baits on Argentine ants in California's coastal vineyards. Crop Prot 25:592-603.

Forschler BT, Evans GM. 1994. Argentine ant (Hymenoptera: Formicidae) foraging activity response to selected containerized baits. J Entomol Sci 29:209-14

Geiger CA, Daane KM. 2001. Seasonal movement and sampling of the grape mealybug, Pseudococcus maritimus (Ehrhorn) (Homoptera: Pseudococcidae) in San Joaquin Valley vineyards. J Econ Entomol 94:291-301.

Giraud T, Pederson JS, Keller L. 2002. Evolution of supercolonies: The Argentine ants of southern Europe. PNAS 99:6075-9.

Godfrey KE, Daane KM, Bentley WJ, et al. 2002. Mealybugs in California vineyards. UC ANR Pub 21612. Oakland, CA.
Golino DA, Sim S, Rill R, Rowhani A. 1999. Four species of California mealybugs can transmit leafroll disease. Am J Enol Viticul 50:367-8.

Greenberg L, Klotz JH. 2000. Argentine ant (Hymenoptera: Formicidae) trail pheromone enhances consumption of liquid sucrose solution. J Econ Entomol 93:119-22.

Greenberg L, Klotz JH, Rust MK. 2006. Liquid borate baits for control of Argentine ant (Linepithema humile) in organic citrus (Hymenoptera: Formicidae). Fl Entomol 89:469-74.

Holway DA, Lach L, Suarez AV, et al. 2002. The causes and consequences of ant invasions. Ann Rev Ecol Syst 33:181-233.

Holway DA, Suarez AV, Case TJ. 1998. Loss of intraspecific aggression in the success of a widespread invasive social insect. Science 282:949-52.

Hooper-Bui LM, Rust MK. 2000. Oral toxicity of abamectin, boric acid, fipronil, and hydramethylnon to laboratory colonies of Argentine ants (Hymenoptera: Formicidae). J Econ Entomol 93:858-64.

Horton JR. 1918. The Argentine ant in relation to citrus groves. USDA Bull No 647:1-73.

Klotz JH, Greenberg L, Amrhein C, Rust MK. 2000. Toxicity and repellency of borate-sucrose water baits to Argentine ants (Hymenoptera: Formicidae). J Econ Entomol 93:1256-8.

Klotz JH, Rust MK, Costa HS, et al. 2002. Strategies for controlling Argentine ants (Hymenoptera: Formicidae) with sprays and baits. J Agric Urban Entomol 19:85-94.

Klotz JH, Rust MK, Gonzalez D, et al. 2003. Directed sprays and liquid baits to manage ants in vineyards and citrus groves. J Agric Urban Entomol 20:31-40.

Klotz JH, Rust MK, Greenberg L, et al. 2006. An evaluation of several urban pest management strategies to control Argentine ants (Hymenoptera: Formicidae). Sociobiol 50:1-8.

Markin GP. 1970. The seasonal life cycle of the Argentine ant, Iridomyrmex humilis (Hymenoptera: Formicidae), in southern California. Ann Entomol Soc Am 63:1238-42.

Nelson EH, Daane KM. 2007. Improving liquid bait programs for Argentine ant control: Bait station density. Environ Entomol 36:1475-84.
Newell W, Barber TC. 1913. The Argentine ant. USDA Bureau of Entomology, Bull No 122. p 1-98.

Phillips P, Sherk C. 1991. To control mealybugs, stop honeydew-seeking ants. Cal Ag 45(2):26-8.

Ripa R, Rodrigues F, Rust MK, Larral I. 1999. Distribution of liquid food and bait in colonies of Argentine ant (Hymenoptera: Formicidae). In: Proc 3rd Int Conf Pests in Urban Environments. Prague, Czech Republic. p 225-9.

Rust MK, Haagsma K, Reierson DA. 1996. Barrier sprays to control Argentine ants (Hymenoptera: Formicidae). J Econ Entomol 89:134-7.

Rust MK, Reierson DA, Klotz JH. 2004. Delayed toxicity as a critical factor in the efficacy of aqueous baits for controlling Argentine ants (Hymenoptera: Formicidae). J Econ Entomol 97:1017-24.

Rust MK, Reierson DA, Paine E, Blum LJ. 2000. Seasonal activity and bait preferences of the Argentine ant (Hymenoptera: Formicidae). J Agric Urban Entomol 17:201-12.

Silverman J, Roulston TH. 2001. Acceptance and intake of gel and liquid sucrose compositions by the Argentine ant (Hymenoptera: Formicidae). J Econ Entomol 94:511-5.

Silverman J, Roulston TH. 2003. Retrieval of granular bait by the Argentine ant (Hymenoptera: Formicidae): Effect of clumped versus scattered dispersion patterns. J Econ Entomol 96:871-4.

Taniguchi G, Thompson T, Sipes B. 2005. Control of the big-headed ant, Pheidole megacephala (Hymonoptera: Formicidae) in pineapple cultivation using Amdro in bait stations. Sociobiol 45:1-7.

Tollerup KE, Rust MK, Dorschner KW, et al. 2004. Low-toxicity baits control ants in citrus orchards and grape vineyards. Cal Ag 58(4):213-7.

Tsutsui ND, Suarez AV, Holway DA, Case TJ. 2000. Reduced genetic variation and the success of an invasive species. PNAS 97:5948-53.

Vega SJ, Rust MK. 2001. The Argentine ant - a significant invasive species in agricultural, urban, and natural environments. Sociobiol 37:3-25.

Vega SJ, Rust MK. 2003. Determining the foraging range and origin of resurgence after treatment of Argentine ant (Hymenoptera: Formicidae) in urban areas. J Econ Entomol 96:844-9. 